Ecological Restoration of Aquatic and Semi-Aquatic Ecosystems in the Netherlands (NW Europe) 


\section{Developments in Hydrobiology 166}

Series editor

H. J. Dumont 


\title{
Ecological Restoration of Aquatic and Semi-Aquatic Ecosystems in the Netherlands (NW Europe)
}

\author{
Edited by \\ P.H. Nienhuis ${ }^{1,2}$ \& R.D. Gulati ${ }^{2}$ \\ ${ }^{1}$ Department of Environmental Studies, University of Nijmegen, The Netherlands \\ ${ }^{2}$ Centre for Limnology, Netherlands Institute of Ecology, Nieuwersluis, The Netherlands
}

Reprinted from Hydrobiologia, volume 478 (2002)

Springer-Science+Business Media, B.V. 


\section{Library of Congress Cataloging-in-Publication Data}

A C.I.P. Catalogue record for this book is available from the Library of Congress.

ISBN 978-90-481-6174-4

ISBN 978-94-017-1335-1 (eBook)

DOI 10.1007/978-94-017-1335-1

\section{Printed on acid-free paper}

All Rights reserved

\section{(C) 2002 Springer Science+Business Media Dordrecht}

Originally published by Kluwer Academic Publishers in 2002

No part of the material protected by this copyright notice may be reproduced

or utilized in any form or by any means, electronic or mechanical,

including photocopying, recording or by any information storage and

retrieval system, without written permission from the copyright owner. 


\section{TABLE OF CONTENTS}

\section{INTRODUCTION}

Ecological restoration of aquatic and semi-aquatic ecosystems in the Netherlands: an introduction

P.H. Nienhuis \& R.D. Gulati

\section{CASE STUDIES}

Ecological restoration in coastal areas in the Netherlands: concepts, dilemmas and some examples

V.N. de Jonge, D.J. de Jong

Restoration of salt marshes in the Netherlands

J.P. Bakker, P. Esselink, K.S. Dijkema, W.E. van Duin, D.J. de Jong

Ecological rehabilitation of the lowland basin of the river Rhine (NW Europe)

P.H. Nienhuis, A.D. Buijse, R.S.E.W. Leuven, A.J.M. Smits, R.J.W. de Nooij, E.M. Samborska

Lakes in the Netherlands, their origin, eutrophication and restoration: state-of-the-art review

Ramesh D. Gulati, Ellen van Donk

The restoration of fens in the Netherlands

Leon P.M. Lamers, Alfons J.P. Smolders, Jan G.M. Roelofs

Towards a decision support system for stream restoration in the Netherlands: an overview of restoration projects and future needs

P.F.M. Verdonschot, R.C. Nijboer

Restoration of brook valley meadows in the Netherlands

A.P. Grootjans, J.P. Bakker, A.J.M. Jansen, R.H. Kemmers

Restoration of aquatic macrophyte vegetation in acidified and eutrophicated shallow soft water wetlands in the Netherlands

J.G.M. Roelofs, E. Brouwer, R. Bobbink 
Restoration of coastal dune slacks in the Netherlands

A.P. Grootjans, H.W.T. Geelen, A.J.M. Jansen, E.J. Lammerts

A review of the past and present status of anadromous fish species in the Netherlands: is restocking the Rhine feasible?

S.J. de Groot

\section{SYNTHESIS}

The state of the art of aquatic and semi-aquatic ecological restoration projects in the Netherlands

P.H. Nienhuis, J.P. Bakker, A.P. Grootjans, R.D. Gulati, V.N. de Jonge 


\section{Preface}

'The Netherlands Water Land' is no commonplace cliché. This small, low-lying delta country, mainly a sedimentary deposit by a number of large European rivers, and situated on the North Sea, contains a large diversity of water bodies. These include both stagnant water and running water; waters in the climax stage of growing solid by peat formation, and shallow, exposed open water bodies; wide, slowly running, turbid rivers and narrow, overshadowed, clear rivulets. In 1989 a symposium was held, under the title 'Netherlands-Wetlands', aiming at presenting an overview of our present knowledge of the structure and functioning of the typical wetlands in the country. The proceedings were published in Hydrobiologia 265 (1993), as well as in Developments in Hydrobiology 88. Major threats to the Dutch wetlands were analysed, and among them the annihilation of original ecosystems, the fragmentation of landscapes, and the acidification and eutrophication of waters and sediments. Emerging perspectives of recovery and restoration, together with a plea for a better insight into the governing ecological processes, were postulated in 1989.

The present multi-author volume, with its twelve main chapters, can be seen as a self-evident successor to the results of the 'Netherlands-Wetlands' symposium. The focus is now fully on the achievements and failures of ecological rehabilitation measures over the past 25 years. Many of these are, indeed, rather impressive. Restoration ecology appears to be a matter of trial and error: in general, progressive restoration endeavours are greatly benefiting from experiences in the past. Many of the completed studies now exemplify an integration of hydrological, geomorphological and ecological knowledge. Brian Moss, a well-known aquatic restoration ecologist stated in Environmental Conservation 27 (2000): "The unit of a freshwater system is not defined by the wetted perimeter of the lake or river but by the limits of the catchment area from which the water is drawn. Conservation of functional values is thus not possible without control of the way the catchment is managed". This general awareness is more and more becoming the dominant way of thinking among the Dutch water policymakers. The stakeholders' attitude is changing towards retreating and abandoning economic activities from vulnerable catchment areas. The trend is now to strive after economic 'win-win' situations, and to reduce human-induced flood hazards in favour of the rehabilitation of more 'natural' wetlands. Sustainable management of aquatic ecosystems means that user functions of the catchments (e.g. navigation, agriculture, urbanisation, recreation) should be accommodated to the dynamics of the natural wetland system, and not the other way around.

The contributions to this book are from invited Dutch experts, all having long standing experience in their respective fields. The authors are affiliated to the state and university research institutions in the Netherlands where restoration ecology and ecological restoration are important disciplines of research, the University of Nijmegen, the State University of Groningen, the University of Utrecht, the Netherlands Institute of Ecology, Alterra and the Netherlands Institute for Fisheries Research. The manuscripts were peer-reviewed by anonymous experts, following the procedures set out for Hydrobiologia.

PiET H. NiENHUIS, Nijmegen

RAMESh D. Gulati, Nieuwersluis 